\title{
Simulation for Optimizing the Hybrid System of Solar Power Plant (SPP) and Diesel Power Plant (DPP) at Balang Lompo Island
}

\author{
A. M. Shiddiq Yunus ${ }^{1, a}$, Makmur Saini ${ }^{1}$, M. Syaiful Fuad ${ }^{1,2}$, and Isradianto ${ }^{1,2}$ \\ ${ }^{1}$ Mechanical Engineering Department, State Polytechnic of Ujung Pandang, Jalan Perintis Kemerdekaan KM. 10, Makassar \\ 90245, Indonesia \\ ${ }^{2}$ PT. PLN, Rayon Pangkep, Indonesia \\ ashiddiq@poliupg.ac.id
}

\begin{abstract}
Balang lompo Island is supplied by Diesel Power Plant (DPP) and Solar Power Plant (SPP), in the operation of SPP it is considered not optimal due to the amount of solar panel capacity of $200 \mathrm{kWp}$ while MPPT capacity of $120 \mathrm{~kW}$ and inverter capacity of $100 \mathrm{kVA}$, with these conditions the research was carried out with the aim of optimizing the generating system on Balang Lompo Island. The optimization of the generating system is conducted by simulation using Homer Legacy Beta software. By entering several important parameters such as technical, economic, and environmental factors therefore, the simulation results obtained in the form of the most optimal system operating patterns represented by one of the smallest net present cost (NPC) parameters, and also the recommended operating hours between DPP and SPP. The research method employed are the preliminary study research, identification and formulation of problems, data collection, data processing using Homer Legacy v2.81 Beta software, and analysis of the simulation results. In this study there are two conditions are compared, the first condition is the existing condition with an MPPT capacity of $120 \mathrm{~kW}$ and an inverter capacity of $100 \mathrm{kVA}$ and the second condition is the addition of MPPT capacity to 200 $\mathrm{kW}$ and an inverter capacity of $200 \mathrm{kVA}$. Based on the results, it can be concluded that with the addition of capacity in SPP equipment, namely MPPT capacity to $200 \mathrm{~kW}$ and inverter capacity to $200 \mathrm{kVA}$, it is proven to be able to save NPC costs, $O \& M$ costs, fuel costs, reduction in DPP operating hours and DPP fuel consumption. With an NPC value of US \$3,362,929 (IDR. 48,957,520,382), with the implementation of this system the NPC cost savings could reach US \$ 197,161 (IDR. 2,870,269,838) during the 25-year operating period, and savings in US fuel/HSD consumption costs $\$ 23,936$ (IDR. 348,460,288) per year.
\end{abstract}

Keywords-Hybrid System, SPP, DPP, Simulation, Homer Software.

\section{Introduction}

Balang Lompo Island is one of the islands in Liukang Tupabbiring District, Pangkep Regency, South Sulawesi Province. Currently the Balang Lompo Island electricity system is supplied by a Diesel Power Plant (DPP) which is managed with a capacity of $2 \times 100 \mathrm{~kW}$ and a Solar Power Plant (SPP) with a capacity of $200 \mathrm{kWp}$.

The operation pattern of the plant on Balang Lompo Island is that it is supplied by the Solar Power Plant (SPP) during the day as suggested in many References [1]-[3] and at night is supplied by the Diesel Power Plant (DPP) [4], [5]. Based on the operating costs of DPP by using fuel oil whose prices are getting higher, and the magnitude of the potential for renewable energy (solar) on Balang Lompo Island, allows it to be utilized as a Hybrid Power Plant (HPP) with SPP to reduce the operating costs of a DPP.

In the Simulation of Hybrid Power Plants (HPP) many involve complex processes caused by several important and interrelated factors that must be considered such as technical, economic, and environmental factors [6]. From a technical point of view, there are several things to consider such as the number and type of generators used (renewable and/or conventional energy), energy storage, converters, loads, whether on-grid or off-grid, the most optimal combination of system components, system performance, control and so on [7]. From an economic perspective, system design needs to calculate lifecycle costs such as initial costs, operational and maintenance costs, equipment/component replacement costs, and so on. While environmental aspects that need to be included in design considerations include greenhouse gas emissions which include the type, amount, and carbon content of the fuel used.

As mentioning in [7], hybrid is the use of two or more power plants with different energy sources, 
generally used for captive generators, so that synergies that provide economic and technical advantages (reliability of supply systems) are obtained. The main purpose of a hybrid system is basically trying to combine two or more energy sources (generating systems) so that they can cover each other's weaknesses and can be achieved supply reliability and economic efficiency at certain types of load, in this case the hybrid SPP-DPP is to combine the advantages DPP \& SPP as well as covering the weaknesses of each generator for certain conditions, so that the overall system can operate more economically and efficiently.

In this paper, a HOMER software package is used to simulate the SPP and DPP. Lambert, Gilman, and Lili, 2006 [8] mentioning that Homer stands for The Hybrid Optimization Model For Electric Renewables, one of the popular tools for the design of HPP systems using renewable energy. Homer simulates and optimizes standalone and grid-connected power generation systems that can consist of a combination of wind turbines, photovoltaic, micro hydro, biomass, diesel generators, microturbine, fuel-cells, batteries, and hydrogen storage, serving electricity and thermal loads.

Homer simulates system operation by providing energy balance calculations for every 8,760 hours in a year. If the system contains a battery and a diesel generator, the homer can also decide for every hour, whether the diesel generator is operating and whether the battery is charged or discharged. Next, the homer determines the best configuration of the system and then estimates the installation and operating costs of the system during its lifetime (lifetime cost) such as initial costs, component replacement costs, O\&M costs, fuel costs, and others. When performing simulations, homer determines all possible system configurations, then displayed sequentially. If sensitivity analysis is needed, homer will repeat the simulation process for each sensitivity variable specified.

\section{Research Methodology}

Research on the effect of adding inverter and MPPT capacity of $200 \mathrm{~kW}$ with 100 inverters and $120 \mathrm{~kW}$ MPPT on the Hyrbrid Power Plant (HPP) on Balang Lompo Island using Homer Legacy V2.81 Beta software.
The research and data collection were carried out on Balang Lompo Island, PT. PLN (Persero) Makassar North Area Rayon Pangkep, Lisdes Balang Lompo Island. This study consists of several stages, namely, the stage of data collection, simulation and data analysis stage. For more details can be seen in Figure 1 .

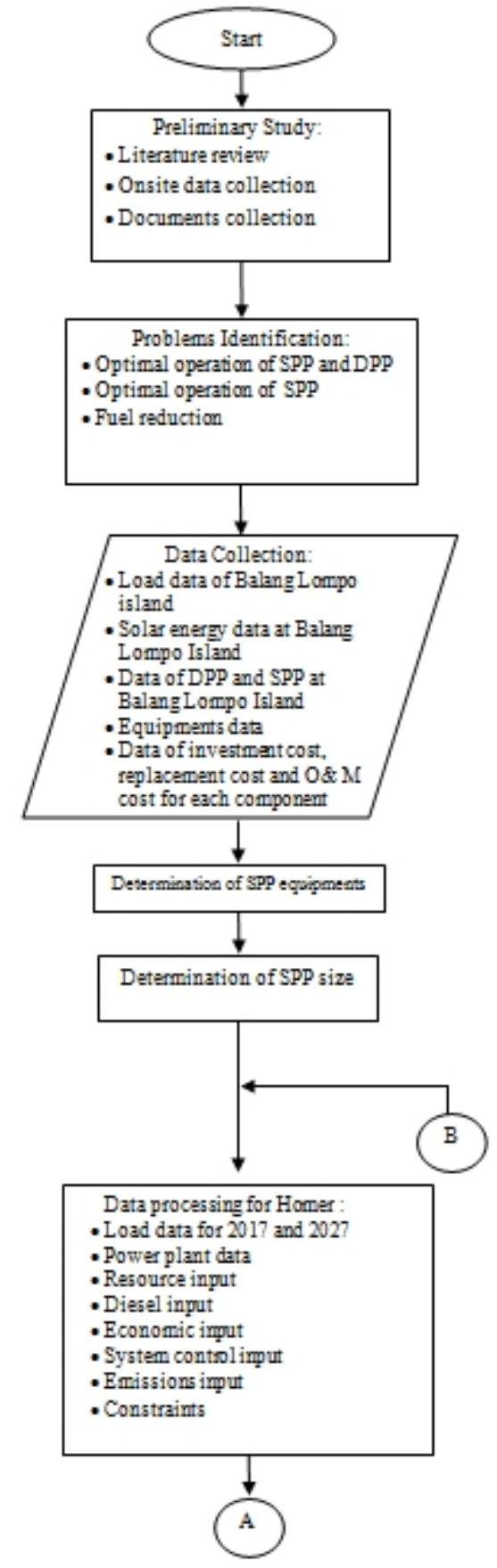




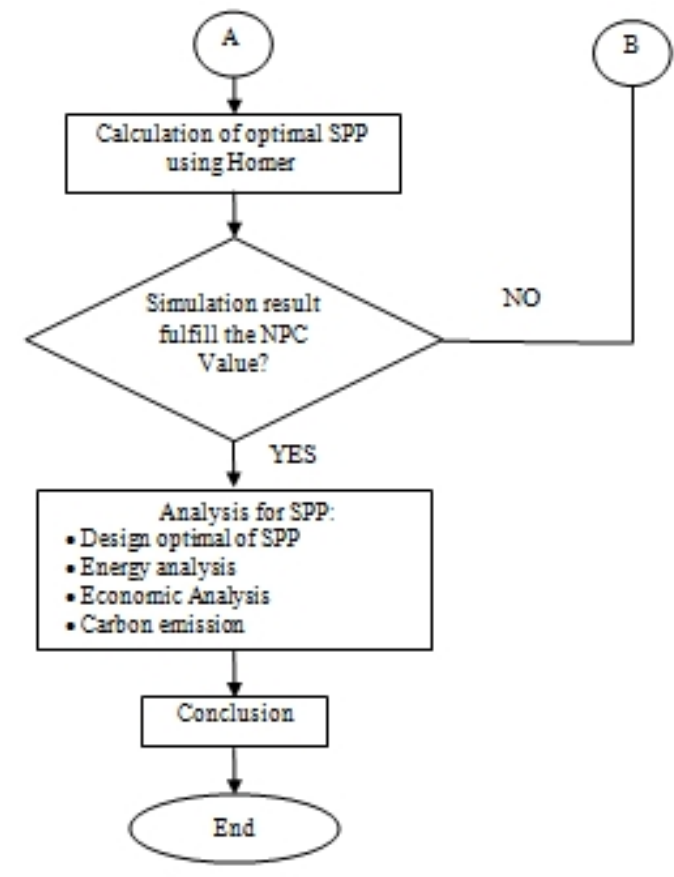

Figure 1. Research Flowchart

\section{Results and Discussion}

\section{A. Simulation Strategy}

For the HPP system simulation strategy is divided into three stages of simulation:

1. The first system simulation is a simulation of the HPP system with the current conditions and is made closer to the actual electricity system of Lisdes Island Balang Lompo. This system consists of generator and installed equipment, namely DPP $2 \times 100 \mathrm{~kW}$, SPP $1 \times 200 \mathrm{kWp}$ with MPPT $120 \mathrm{~kW}$ and $100 \mathrm{kVA}$ inverter with load conditions in 2017.

2. The second system simulation is a HPP system simulation with the addition of equipment capacity using MPPT $200 \mathrm{~kW}$ and $200 \mathrm{kVA}$ inverter with load conditions in 2017.

3. The third system simulation is a simulation of HPP system with the addition of equipment capacity by using MPPT $200 \mathrm{~kW}$ and $200 \mathrm{kVA}$ inverter with load conditions in 2027.

For 2017 load conditions, the daily electricity consumption to be served is $2289 \mathrm{kWh}$. As for the load condition of 2027, the daily electricity consumption to be served is $2476 \mathrm{kWh}$. The simulation results of the three HPP systems with Homer will obtain an optimal configuration design and the results will be compared and choose the HPP system for discussion based on the lowest net present cost (NPC) value.
B. Simulation Results of HPP during Consumer Load in 2017.

1. The results of the first system simulation with load conditions in 2017.

The first system that was simulated was a plant installed on the Balang Lompo Island system which is a current condition and used as a comparison for the second system, this system was made close to the actual conditions consisting of $2 \times 100 \mathrm{~kW}$ DPP and $1 \times 200 \mathrm{kWp}$ SPP with $120 \mathrm{~kW}$ MPPT equipment capacity and 100 kVA inverter with load conditions 2017. The NPC value from the simulation and optimization of the first system is US $\$ 3,560,090$. The main data from the first system simulation and optimization results can be seen in the table 1 .

Table 1. Simulation Results for the First System

\begin{tabular}{|l|c|}
\hline \multicolumn{1}{|c|}{ Parameters } & $\begin{array}{c}\text { DPP 2 X 100 Kw } \\
\text { SPP 1 X 200 kWp } \\
\text { Inverter 100 kVA } \\
\text { MPPT 120 kW }\end{array}$ \\
\hline Net present cost(US\$) & 3.560 .090 \\
\hline Capital cost (US\$) & 0 \\
\hline Operating cost(US\$/ year) & 278.494 \\
\hline Cost of energy(US\$/kWh) & 0,332 \\
\hline O\&M cost (US\$/ year) & 3.639 \\
\hline Fuel cost (US\$/ year) & 267.420 \\
\hline Annual cost(US\$/ year) & 278.494 \\
\hline $\begin{array}{l}\text { Electric Power Production } \\
\text { (kWh/ year) }\end{array}$ & 903.364 \\
\hline $\begin{array}{l}\text { Energy Consumption (kWh/ } \\
\text { year) }\end{array}$ & 838.760 \\
\hline $\begin{array}{l}\text { Fuel Consumption/HSD (liter/ } \\
\text { year) }\end{array}$ & 325.804 \\
\hline Renewable fraction (\%) & 0,22 \\
\hline Emission/CO $(\mathrm{kg} /$ year) & 857.949 \\
\hline
\end{tabular}

1. The results of the secondt system simulation with load conditions in 2017.

The second system that was simulated consisted of the current installed generator DPP $2 \times 100 \mathrm{~kW}$ and SPP $1 \times 200 \mathrm{kWp}$ with the addition of MPPT equipment capacity to $200 \mathrm{~kW}$ and inverter to $200 \mathrm{kVA}$ with load conditions in 2017. The NPC value from the simulation and optimization of the second system was US \$ $3,560,090$. The main data from the first system simulation and optimization results can be seen in the table 2. 
Table 2. Simulation Results for the Second System

\begin{tabular}{|l|c|}
\hline \multicolumn{1}{|c|}{ Parameter } & $\begin{array}{c}\text { DPP 2 X 100 Kw } \\
\text { SPP 1 X 200 kWp } \\
\text { Inverter 200 kVA } \\
\text { MPPT 200 kW }\end{array}$ \\
\hline Net present cost(US\$) & 3.362 .929 \\
\hline Capital cost (US\$) & 122.547 \\
\hline Operating cost(US\$/ year) & 253.484 \\
\hline Cost of energy(US\$/kWh) & 0,314 \\
\hline O\&M cost (US\$/ year) & 3.317 \\
\hline Fuel cost (US\$/ year) & 243.484 \\
\hline Annual cost(US\$/ year) & 263.071 \\
\hline $\begin{array}{l}\text { Electric Power Production (kWh/ } \\
\text { year) }\end{array}$ & 972.343 \\
\hline Energy Consumption $(\mathrm{kWh} /$ year) & 838.642 \\
\hline Fuel Consumption/HSD (liter/ year) & 296.643 \\
\hline Renewable fraction $(\%)$ & 0,34 \\
\hline Emission/CO ${ }_{2}(\mathrm{~kg} /$ year) & 781.158 \\
\hline
\end{tabular}

3. Comparison of optimal simulation results of the first and second systems

Comparison of the results of the simulation of the first system with the second system is carried out to find out how much influence the second system has in reducing the NPC value of the first system for 25 years. The comparison of the first and second system NPC values can be seen in Figure 2.

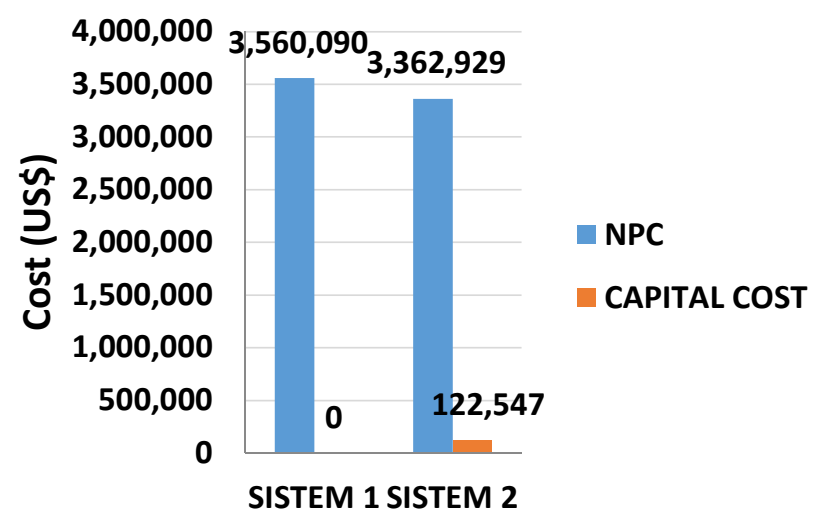

Figure 2. Comparison of first and second system NPC values and capital costs

From the comparison chart above, the first system NPC is US \$ 3,560,090 and the second system is US \$ $3,362,929$. The value of the second system NPC obtained is smaller than the first system with a difference of US $\$ 197,161$. So with the application of the second system NPC cost savings that can be made reach US \$ 197,161 for 25 years of system operation. With the DOI : http://dx.doi.org/10.31963/intek.v7i1.2133 application of the second system in reducing NPC costs, an investment cost of US \$122,547 is needed to increase the capacity of MPPT and inverter equipment.

From the results of simulation and optimization with Homer HPP system design with the addition of MPPT equipment capacity to $200 \mathrm{~kW}$ and inverter to $200 \mathrm{kVA}$ also makes the HPP system more optimal according to load requirements.

4. The results of a third system simulation with a load condition in 2027

By looking at the simulation of an increase in electricity consumption in Balang Lompo Island in 2027 which is relatively small at $903,770 \mathrm{kWh}$ or up 65,000 $\mathrm{kWh}$ compared to electricity consumption in 2017 , the third system is simulated using the same unit and equipment as the second system because it is still considered sufficient and able to meet the electricity consumption needs of Balang Lompo Island until 2027.

The third system that was simulated consisted of $2 \times 100$ kW DPP, SPP $1 \times 200 \mathrm{kWp}$ and $200 \mathrm{~kW}$ MPPT and 200 kVA inverter with load conditions in 2027. From the results of simulation and optimization with Homer the system design simulation was able to meet the needs of electricity consumption in Balang Lompo Island until the year 2027 with an NPC value of US \$3,586,068. The main data of the results of the third system simulation and optimization can be seen in the table 3 below.

Table 3. Simulation result for the third system

\begin{tabular}{|l|c|}
\hline \multicolumn{1}{|c|}{ Parameters } & $\begin{array}{c}\text { DPP 2 X 100 Kw } \\
\text { SPP 1 X 200 kWp } \\
\text { Inverter 200 kVA } \\
\text { MPPT 200 kW }\end{array}$ \\
\hline Net present cost(US\$) & 3.586 .068 \\
\hline Capital cost (US\$) & 122.547 \\
\hline Operating cost(US\$/year) & 270.940 \\
\hline Cost of energy(US\$/kWh) & 0,311 \\
\hline O\&M cost (US\$/year) & 3.338 \\
\hline Fuel cost (US\$/ year) & 260.849 \\
\hline Annual cost(US\$/ year) & 280.526 \\
\hline Electric Power Production (kWh/ & 1.031 .152 \\
year) & 903.412 \\
\hline Energy Consumption $(\mathrm{kWh} /$ year) & 317.799 \\
\hline Fuel Consumption/HSD (liter/ year) & 0,32 \\
\hline Renewable fraction $(\%)$ & 836.869 \\
\hline Emission/CO ${ }_{2}(\mathrm{~kg} /$ year) & \\
\hline
\end{tabular}

After obtaining the optimal design of the HPP system with $2 \times 100 \mathrm{~kW}$ DPP installed plant and $1 \times 200$ kWp SPP and adding MPPT equipment capacity to 200 $\mathrm{kW}$ and inverter to $200 \mathrm{kVA}$ with an NPC value of US \$ 3,362,929 for load conditions in 2017 and US \$ 
$3,586,068$ for conditions load in 2027, then in this section discussions will be carried out on parameters of HPP systems obtained at the simulation stage including HPP system capacity, HPP system electricity production, hours of generating operation, generator fuel consumption and $\mathrm{CO}_{2}$ emissions reduction.

1. Discussion of the optimal design of the HPP system under load conditions in 2017.

\section{A. HPP system capacity under load conditions in 2017}

The capacity of the HPP system consists of renewable energy generation of $200 \mathrm{kWp}$ on a $1 \times 200$ $\mathrm{kWp}$ SPP unit and a conventional generator of $200 \mathrm{~kW}$ consisting of $2 \times 100 \mathrm{~kW}$ DPP units and the addition of MPPT equipment capacity to $200 \mathrm{~kW}$ and inverter to $200 \mathrm{kVA}$. Of all the generating units and equipment simulated in the second system, the SPP unit has the largest capacity factor of $18.9 \%$ while the DPP units in units 1 and 2 are $32.2 \%$ and $47.2 \%$, respectively. The following details the capacity of each generator that has been simulated.

Table 4. Capacity of HPP system under load conditions in 2017.

\begin{tabular}{|l|c|c|c|c|c|}
\hline $\begin{array}{c}\text { Power } \\
\text { Plant }\end{array}$ & $\begin{array}{c}\text { Install } \\
\text {-ed } \\
\text { Capac } \\
\text {-ity } \\
(\mathbf{k W})\end{array}$ & $\begin{array}{c}\text { Avera- } \\
\text { ged } \\
\text { Output } \\
\text { power } \\
(\mathbf{k W})\end{array}$ & $\begin{array}{c}\text { Capaci- } \\
\text { ty factor } \\
\mathbf{( \% )}\end{array}$ & $\begin{array}{c}\text { Min } \\
\text { Output } \\
\text { Power } \\
(\mathbf{k W})\end{array}$ & $\begin{array}{c}\text { Max } \\
\text { Output } \\
\text { Power } \\
(\mathbf{k W})\end{array}$ \\
\hline SPP & 200 & 38 & 18,9 & 0 & 193 \\
\hline DPP1 & 100 & 55,8 & 32,2 & 28,2 & 94 \\
\hline DPP2 & 100 & 78,2 & 47,2 & 27,3 & 91 \\
\hline
\end{tabular}

B. Electricity production of HPP system at load conditions in 2017

In this second system simulation a renewable fraction value of $34 \%$ is obtained, which means $34 \%$ of the total electricity production of the HPP system is generated from renewable energy generation. The total electricity production as a whole HPP system is $972,343 \mathrm{kWh}$ while the electricity consumption of the Balang Lompo Island system is $838,642 \mathrm{kWh}$, the overall electrical energy needs of the Balang Lompo Island system can be met as a whole with an over production of $70,674 \mathrm{kWh}$. The following details the production of HPP system electric energy:

Table 5. Production of HPP system electricity at load conditions in 2017.

\begin{tabular}{|c|c|}
\hline $\begin{array}{c}\text { Power } \\
\text { Plant }\end{array}$ & $\begin{array}{c}\text { Operation hours } \\
\text { (hour/year) }\end{array}$ \\
\hline
\end{tabular}

DOI : http://dx.doi.org/10.31963/intek.v7i1.2133

\begin{tabular}{|l|c|c|}
\hline & $\begin{array}{c}\text { First System } \\
\text { Simulation }\end{array}$ & $\begin{array}{c}\text { Second System } \\
\text { Simulation }\end{array}$ \\
\hline SPP & 198.617 & 331.027 \\
\hline DPP1 & 261.086 & 264.925 \\
\hline DPP2 & 443.662 & 376.391 \\
\hline Total & 903.365 & 972.343 \\
\hline
\end{tabular}

C. HPP system operating hours at load condition in 2017

The operating hours of the plant based on the simulation results for renewable energy generating $1 \times 200 \mathrm{~kW}$ reached 4,380 hours/year while for DPP in units 1 and 2 each unit was 4,749 hours / year and 4,816 hours/year. Complete operating hours for each generating unit can be seen in table 6 .

Table 6. Operation hours of HPP system generator at load conditions in 2017

\begin{tabular}{|l|c|c|}
\hline \multirow{2}{*}{$\begin{array}{c}\text { Power } \\
\text { Plant }\end{array}$} & \multicolumn{2}{|c|}{$\begin{array}{c}\text { Operation hours } \\
\text { (hour/year) }\end{array}$} \\
\cline { 2 - 3 } & $\begin{array}{c}\text { First System } \\
\text { Simulation }\end{array}$ & Second System Simulation \\
\hline SPP & 4.380 & 4.380 \\
\hline DPP1 & 4.751 & 4.749 \\
\hline DPP2 & 5.756 & 4.816 \\
\hline
\end{tabular}

D. HPP system fuel consumption at load condition in 2017

Special fuel consumption for $2 \times 100 \mathrm{~kW}$ DPP units in the first system simulation is 325,804 liters/year while in the second system simulation fuel consumption for $2 \times 100 \mathrm{~kW}$ DPP units is 296,643 liters/year. The savings in fuel consumption that can be done reach 29,161 liters/year by implementing this second system. The following details the generator fuel consumption.

Table 7. Consumption of HPP system fuel consumption under load conditions in 2017

\begin{tabular}{|l|c|c|}
\hline \multirow{2}{*}{ Power Plant } & \multicolumn{2}{|c|}{$\begin{array}{c}\text { Operation hours } \\
\text { (hour/year) }\end{array}$} \\
\cline { 2 - 3 } & $\begin{array}{c}\text { First System } \\
\text { Simulation }\end{array}$ & $\begin{array}{c}\text { Second System } \\
\text { Simulation }\end{array}$ \\
\hline SPP & - & - \\
\hline DPP1 & 127.855 & 129.194 \\
\hline DPP2 & 197.949 & 167.448 \\
\hline Total & 325.804 & 296.643 \\
\hline
\end{tabular}

E. Reduction in $\mathrm{CO}_{2}$ emissions of HPP systems under load conditions in 2017

Based on the simulation results for the first system the amount of $\mathrm{CO}_{2}$ emissions produced was 857,949 
$\mathrm{kg} /$ year while the results of the second system simulation obtained the amount of $\mathrm{CO}_{2}$ emissions produced by $781,158 \mathrm{~kg} /$ year. With the application of the second system, a reduction in the amount of $\mathrm{CO}_{2}$ emissions can be carried out by $76,791 \mathrm{~kg} /$ year.

\section{F. Production costs (cost of energy) of the HPP system at 2017 load conditions}

Based on the simulation results for the first system energy production costs of US $\$ 0.332 / \mathrm{kWh}$ while the second system is US $\$ 0.314 / \mathrm{kWh}$. The decrease in the cost of the second system energy production was due to increased production of the SPP so that the production of the DPP unit was reduced and the annual component cost of the DPP unit was reduced.

2. Discussion on the optimal design of HPP systems under load conditions in 2027

\section{A. HPP system capacity under load conditions in 2027}

The capacity of the HPP system consists of renewable energy generation of $200 \mathrm{kWp}$ on a $1 \times 200$ $\mathrm{kWp}$ SPP unit and a conventional generator of $200 \mathrm{~kW}$ consisting of $2 \times 100 \mathrm{~kW}$ DPP units and the addition of MPPT equipment capacity to $200 \mathrm{~kW}$ and inverter to $200 \mathrm{kVA}$ or the same as simulating "condition 2" . Of all the simulated generating units in the third system, the SPP unit has a capacity factor of $18.9 \%$ while the DPP units in units 1 and 2 are $36.5 \%$ and $50.2 \%$, respectively. The following details the capacity of each generator that has been simulated.

Table 8. Capacity of HPP systems under load conditions in 2027

\begin{tabular}{|l|c|c|c|c|c|}
\hline $\begin{array}{c}\text { Power } \\
\text { Plant }\end{array}$ & $\begin{array}{c}\text { Install- } \\
\text { ed } \\
\text { Capac- } \\
\text { ity } \\
\text { (kW) }\end{array}$ & $\begin{array}{c}\text { Avera- } \\
\text { ged } \\
\text { Output } \\
\text { power } \\
(\mathbf{k W})\end{array}$ & $\begin{array}{c}\text { Capac } \\
\text {-ity } \\
\text { factor } \\
\mathbf{( \% )}\end{array}$ & $\begin{array}{c}\text { Min } \\
\text { Output } \\
\text { Power } \\
(\mathbf{k W})\end{array}$ & $\begin{array}{c}\text { Max } \\
\text { Output } \\
\text { Power } \\
(\mathbf{k W})\end{array}$ \\
\hline SPP & 200 & 38 & 18,9 & 0 & 193 \\
\hline DPP1 & 100 & 63,1 & 36,5 & 28,2 & 94 \\
\hline DPP2 & 100 & 82,2 & 50,2 & 27,3 & 91 \\
\hline
\end{tabular}

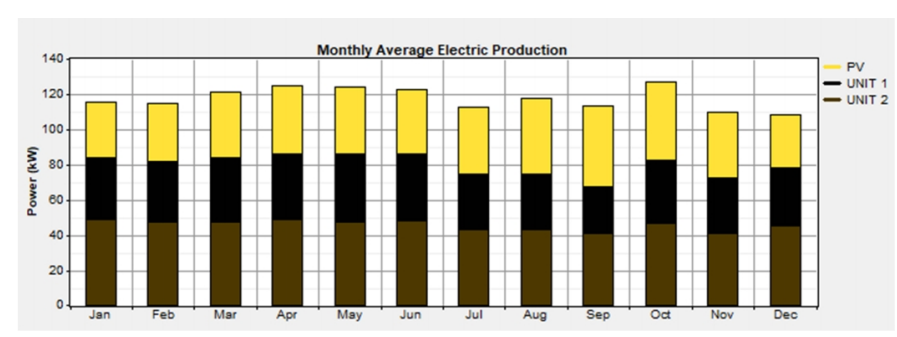

Figure 3. Averaged Output Power of HPP on load condition in 2027
B. Electricity production of HPP systems under load conditions in 2027

In this third system simulation the total total electricity production of the HPP system is $1,031,152$ $\mathrm{kWh}$ while the electricity consumption of the Balang Lompo Island system is $903,412 \mathrm{kWh}$, the overall electrical energy needs of the Balang Lompo Island system are still able to be met annually by the SPP and DPP units and equipment - equipment installed. The following details the production of HPP system electric energy.

Table 9. Electricity energy production of HPP systems at load conditions in 2027

\begin{tabular}{|l|c|c|}
\hline \multirow{2}{*}{$\begin{array}{c}\text { Power } \\
\text { Plant }\end{array}$} & \multicolumn{2}{|c|}{$\begin{array}{c}\text { Operation hours of each power plant } \\
\text { (hour/year) }\end{array}$} \\
\cline { 2 - 3 } & $\begin{array}{c}\text { Load Condition } \\
\text { in 2017 }\end{array}$ & $\begin{array}{c}\text { Load Condition in } \\
\mathbf{2 0 2 7}\end{array}$ \\
\hline SPP & 4.380 & 4.380 \\
\hline DPP1 & 4.749 & 4.757 \\
\hline DPP2 & 4.816 & 4.867 \\
\hline
\end{tabular}

C. HPP system operating hours at load conditions in 2027

The operating hours of the plant are based on simulation results for renewable energy generation of $1 \times 200 \mathrm{~kW}$ SPP, which is 4,380 hours/year DPP on units 1 and 2 of each unit of 4,757 hours/year and 4867 hours / year. Table 10 shows the same operating hours for SPP under load conditions in 2017 and 2027 while for DPP itself there was an increase in operating hours of DPP units by 56 hours / year. The complete operating hours of each generating unit can be seen in the following table.

Table 10. The operating hours of HPP system generators under load conditions in 2027

\begin{tabular}{|l|c|c|}
\hline \multirow{2}{*}{$\begin{array}{c}\text { Power } \\
\text { Plant }\end{array}$} & \multicolumn{2}{|c|}{$\begin{array}{c}\text { Operation hours of each power plant } \\
\text { (hour/year) }\end{array}$} \\
\cline { 2 - 3 } & $\begin{array}{c}\text { Load Condition in } \\
\mathbf{2 0 1 7}\end{array}$ & $\begin{array}{c}\text { Load Condition in } \\
\mathbf{2 0 2 7}\end{array}$ \\
\hline SPP & 4.380 & 4.380 \\
\hline DPP1 & 4.749 & 4.757 \\
\hline DPP2 & 4.816 & 4.867 \\
\hline
\end{tabular}

D. Fuel consumption in the HPP system under load conditions in 2027

The special fuel consumption for the $2 \times 100 \mathrm{~kW}$ DPP unit in the second simulation with load conditions in 2017 is 296,643 liters/year while in the third system

DOI : http://dx.doi.org/10.31963/intek.v7i1.2133 
simulation with load conditions in 2027 is 317,799 liters/year or an increase of 21,156 liters/year. The following details the generator fuel consumption.

Table 11. Fuel consumption in the HPP system under load conditions in 2027

\begin{tabular}{|l|c|c|}
\hline \multirow{2}{*}{$\begin{array}{c}\text { Power } \\
\text { Plant }\end{array}$} & \multicolumn{2}{|c|}{$\begin{array}{c}\text { Operation hours of each power plant } \\
\text { (hour/year) }\end{array}$} \\
\cline { 2 - 3 } & $\begin{array}{c}\text { Load Condition } \\
\text { in 2017 }\end{array}$ & $\begin{array}{c}\text { Load Condition } \\
\text { in 2027 }\end{array}$ \\
\hline SPP & - & - \\
\hline DPP1 & 129.194 & 141.713 \\
\hline DPP2 & 167.448 & 176.086 \\
\hline Total & 296.643 & 317.799 \\
\hline
\end{tabular}

E. Reduction in the amount of $\mathrm{CO}_{2}$ emissions of the HPP system under load conditions in 2027

Based on the simulation results for the second system with 2017 load conditions, the amount of $\mathrm{CO}_{2}$ emissions produced was $781,158 \mathrm{~kg} /$ year while the results of the third system simulation with load conditions in 2027 obtained the amount of $\mathrm{CO}_{2}$ emissions produced by $836,869 \mathrm{~kg} /$ year or an increase of $82,711 \mathrm{~kg} /$ year .

\section{F. Production costs (cost of energy) for the HPP system} under load conditions 2027

Based on the simulation results for the second system energy production costs with load conditions in 2017 amounted to US $\$ 0.314 / \mathrm{kWh}$ while the third system with load conditions in 2027 was US \$ $0.311 / \mathrm{kWh}$.

\section{Conclusion}

1. By simulating the HPP system on the Balang Lompo Island electricity system with a combination of DPP and increasing SPP equipment capacity to $200 \mathrm{~kW}$ MPPT and $200 \mathrm{kVA}$ inverters proved to be able to save NPC costs, O\&M costs, fuel costs, reduction in DPP operating hours and DPP fuel consumption .

2. For load conditions in 2017, the optimal design of the HPP system obtained is a second system consisting of a combination of $2 \times 100 \mathrm{~kW}$ DPP units and $1 \times 200 \mathrm{kWp}$ SPP with $200 \mathrm{kVA}$ inverters and $200 \mathrm{~kW}$ MPPT with NPC values of US \$ $3,362,929$ (IDR. 48,957,520,382), with the implementation of this system NPC cost savings can reach US \$ 197,161 (IDR. 2,870,269,838) during the 25-year operating period, saving on fuel/HSD consumption costs of US \$23,936 (IDR. $348,460,288$ ) per year .

3. For the condition in 2027, the design of the HPP system in the second condition is still sufficient to meet the estimated load requirement of 903,770 $\mathrm{kWh}$ with an NPC value of US $\$ 3,586,068$ (IDR. $52,205,977,944)$, during the 25-year operating period, and fuel/HSD consumption costs US \$ 260,849 (IDR. 3,797,439,742) per year.

\section{Acknowledgement}

Authors would like to thank PT. PLN Rayon Pangkep for the data supply to conduct the research.

\section{References}

[1] Nurrachman. "Pengembangan Energi Surya untuk PLTS di Indonesia", (Development of Solar Energy for PLTS in Indonesia). Yogyakara: APAMSI (Asosiasi Pabrikan Modul Surya Indonesia). 2013.

[2] PT PLN (Persero). "Panduan Umum Sistem Pembangkit Listrik Tenaga Surya", (General Guidelines for Solar Power Generation Systems). Jakarta. 2012.

[3] Rotib, Widy. "Aplikasi Sel Surya Sebagai Sumber Energi Alternatif", (Application of Solar Cells as Alternative Energy Sources), Dimensi Vol. 4 No. 1 Juni 2001, Institute for Science and Technology Studies (ISTECS), Jepang. 2001.

[4] PT PLN (Persero). "Operasi Pemeliharaan PLTS", (Operation Maintenance of SPP). Jakarta. 2012

[5] PT PLN (Persero) Pusat Pendidikan dan Pelatihan. "Pembangkit Listrik Tenaga Diesel", (Diesel Power Plant). Jakarta. 2012.

[6] Teguh Utomo, Sean Yudha, Yahya, Soeprapto, "Analisis Pembangkit Listrik Hibrida (PLH), Diesel dan Energi Terbarukan Di Pulau Mandangin, Sampang, Madura Menggunakan Software Homer", (Analysis of Hybrid Power Plants (PLH), Diesel and Renewable Energy on Mandangin Island, Sampang, Madura Using Homer Software). Jurnal Mahasiswa Teknik Elektro Universitas Brawijaya, Vol. 2, No. 2, 2014.

[7] Yoga, Tegar Krisna. "Studi Ekonomi Sistem Penyedia Cadangan Daya Hybrid Bayu-Diesel-Studi Kasus: Di Hotel Queen Of The South Beach Resort." (Economic Study of the Wind-Diesel Hybrid Power Reserve Provider System-A Case Study: At the Queen of The South Beach Resort Hotel). Final Research Report, Yogyakarta: Teknik Elektro Universitas Islam Indonesia. 2018.

[8] Lambert, T., P. Gilman, dan P. Lilienthal, "Micropower System Modeling with HOMER, in Integration of Alternative Sources of Energy, ed. Felix A. Farret and M. Godoy Simoes, John Wiley \& Sons, Inc. 2006. 